\title{
IMPROVING STUDENTS’ VOCABULARY THROUGH SONGS
}

\author{
Ilinawati, Yokie Prasetya Darma \\ STKIP Persada Khatulistiwa \\ ilina_selvin@yahoo.com,12yokieprasetya@gmail.com
}

\begin{abstract}
The study was about improving students' vocabulary through English song. The subject of the study were first semester students of English language study program, STKIP Persada Khatulistiwa Sintang,Academic Year 2018/2019 which consisted of 22 students. This study aimed to increase students' vocabulary through songs.The method of this research was qualitative research and the object was teaching vocabulary through English song.This was classroom action research which consisted of one cycle.In collecting the data, the researchers used observation sheet, Fieldnotes and test. The result of this research showed that the use of song succeeded improving students' vocabulary. The result of the test shown that mean score was 80,25 , it was good cathegory.The improvement of the teaching learning process was based on the improvement of teaching learning behaviour in the classroom. The change of behaviour was notified from the classroom observation, fieldnotes which were discussed with the collaborator in the reflection stage. Song was found out helpful to improve students' vocabulary mastery for first semester students of English language study program, STKIP Persada Khatulistiwa Sintang, Academic year 2018/2019.
\end{abstract}

Keywords: Vocabulary Mastery, English Songs

\section{INTRODUCTION}

Language is mean of communication.Creating good comunication means having an ability to enrich herself/himself with many knowledges about language.In global era, English language becomes the most important language for communication. As we know that almost all aspects of life use English in terms of cummnication.Therefore, it really needed to master English for better communication. In Secondary school, English is one of compulsory subject that must be learned. To support the mastery of English skills, the students should learn vocabulary as basic of communication.

Rai (2010, p. 112) mentions vocabulary is a list of words, usually given in alphabetical order. Speaking of technical vocabulary, medical vocabulary and legal vocabulary to mean the list of words needed to describe concepts in that subject and used for discourse in that subject. Vocabulary also means the stock of words used by a person. Furthermore, Rai says one usually has a passive vocabulary of words that one can understand when one hears or reads them and an active vocabulary of words which one uses for speaking or writing. Reading and writing vocabulary is larger than our spoken vocabulary because there is time to make an effort to recall words when one reads or writes; speech flows faster and there is less time to recall words. So, reading vocabulary (passive one) is the largest and spoken vocabulary (active one) is the smallest; one uses all the words one knows when one is reading and uses the fewest of the words. According to Fries ( 1975:38 ) vocabulary is the essential of language learning that 
contains the words in the forms of noun, adjective, verb and adverb which will make language meaningful.

Vocabulary is essential element to construct senetences. In order to be able to construct sentences, it needs for students to improve their vocabulary. However, most first semester students of English language study program STKIP Persada Khatulistiwa Sintang, faced problems in vocabulary mastery especially for understanding the meaning of the words, identifying the words and using the words. The students could not speak English well because of their limited vocabularies. Based on the interview with the lecturer who teach vocabulary subject, it was found that mosf of first semester students of English language study program STKIP Persada Khatulistiwa were lack of vocabulary.

Referring to the problem above, lecturer should provide the best solution to accomodate the students problem by using media.One of the media in teaching vocabulary is song. Song is an interesting media that can help the students to memorize the words, beside that, song also can motivate the students to know the meaning of the words further. Considering the appropriate song is very important, because it will influence the students motivation to study.It assumed that if the students are motivated to learn vocabulary, they will enjoy in following the study process. So, they will be easy and fun to communicate with other people.The reseracher focused on the investigating the students vocabulary achievement by after being taught by using song. Dale ( $1992: 5$ ) states that songs are good at introducing vocabulary because song gives a meaningful context for vocabulary. Media provides an enjoyable situation for students. From various songs, the students can learn many vocabulary. Songs is a useful means to facilitate in learning of vocabulary, sentence structure, and sentence patterns, not to mention their reflectivity of mother tongue culture. When the lecturer will apply songs in her learning process, she has to know what kinds of song and what contribution of to the her learning material.

The reseracher as lecturer used song lyric to teach vocabulary and the technique used was Audio Lingual Method ( ALM ). Based on the problems above, the researchers intend to conduct an action research to first semester students of English language study program STKIP Persaa Khatulistiwa, Sintang, Academic year 2018/2019.

\section{METHOD}

This research was a classroom action research. It was conducted in one cycle. Focused on seeking solution to problems of classroom management, instructional strategies, use of materials, or student learning. Burns cited in Richards and Farrell (2005, p. 11) defines that professional development activities such as action research are "integrated into school or organizational change as a significant way of facilitating school curriculum renewal and 
ensuring that language teachers maintain greater ownership of curriculum implementation."Ary, Jacobs, Sorensen and Razavieh (2010, p. 637) define a classroom action research as a research conducted in the classrooms with the object of improving classroom practices or improving practices in the school. Wallace cited in Mackey and Gass (2005, p. 216) maintains that action research is principally a way of reflecting on teaching by systematically collecting data on everyday practice and analyzing it in order to come to some decisions about what the future practice should be. So, classroom action research is a method of finding out what works best in one's classroom so that s/he can improve student learning.

The research participants were first semester students of English language study program STKIP Persada Khatulistiwa, Sintang. Academic year 2018/2019. They consisted of 18 females and 4 males. This research, applied the observation and measurement techniques to collect the data. Best and Kahn (2006, p. 265) define observations as of the setting physical environment, social interactions, physical activities, nonverbal communications, planned and unplanned activities and interactions, and unobtrusive indicators. Observation enables the researcher to understand the context of program, to be open-ended and inductive, to see things that might otherwise be unconsciously missed, and to discover things that participants might not freely talk about in interview situations, to move beyond perception based data and to access personal knowledge. A measurement is process through which researchers describe, explain, and predict the phenomena and constructs of our daily existence. The importance of measurement in research design cannot be overstated. Even the well-designed studies will prove useless if inappropriate measurement strategies are used in the data collection stages (Marczyk, DeMatteo, \& Festinger, 2005, p. 95). The measurement technique was aimed to see students score in learning vocabulary. The tool of the measurement was test of vocabulary. The test was given in the acting stage.

\section{FINDING AND DISCUSSION}

The research was conducted at the first semester students of English language study program of STKIP Persada Khatulitiwa Sintang, Academic year 2018/2019. There was one cycles in teaching vocabulary to the students. The cycle was conducted in two meetings. The implementation of song in the class consisted of planning, action, observation and refection.

In the first cycle, the reseracher prepared learning devices to teach vocabulary.It included syllabus, material which taken from English text book, English songs and other sources which taken from internet.The action was conducted in two meetings, on 2nd October 2018 and 3rd October 2018. The lesson started at 08.10- 09.55 am. 


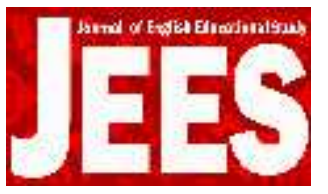

Journal of English Educational Study

Volume 1 Issue 2 November 2018 Page 66-70

E-ISSN: 2655-0776

Teaching vocabulary was implemented through English song in the classroom. The students sang the song together and they were happy because the songs were familiar for them. Most of the students respond the lesson well. They were enthusiastic to find the meaning of the words and tried to pronounce the words. They were always active to ask the lecturer about the difficult words and meaning. They tried to identify the words based on their cluster and tried to make a sentence. Either first meeting or second meeting, students were happy and fun. At the end of second meeting, they students were given a test. Test in form of identifying the words and find the meaning through song.

Briefly, in the first cycle, the students felt happy and enthusiastically to follow the classroom activity.They were motivated to learn vocabulary through song and they were also motivated to participate and active to the lesson.It would be easier for students to memorize the words by singing English song.

The result of the obeservation through students observation sheet and observation towards lecturer activities shown that there was improvement of students vocabulary and responses. In the second meeting, the teaching - learning process improved better that the first meeting.. Furthermore, the result of fieldnote were also showing good performance both lecturer and students.The reserachers delivered the material well. The reserachers was also more confident in conveying the material The students were enthusiastic and their pronunciation improved gradually and they were not shy, because they could have a lot of practice and they could asked their friends and lecturer if they found any difficulties wordsThe students mean score was 80,25 . It was good chategory. It meant students shown their seriousness to follow the lesson and to improve their English vocabulary..

On Reflection phase, reseracher and observer tried to make the decision wheather the cycle would be continued or stopped. Considering to the result above, researcher and observer decided that the research stop at the first cycle.From the result of data collection tools ( observation, fielnotes and test ) shown that the first cycle was successful.

\section{CONCLUSION}

Based on the results of the research which amied to improve students vocabulary mastery through song to the first semester students of English language study program STKIP Persada Khatulistiwa Sintang, consisted of 18 females and 4 males. The researcher found that the use of song effectively improved the students'vocabulary mastery and teaching learning process. The reserach findings could be concluded that teaching vocabulary through song improved their students' vocabulary in several aspects; they were : ( 1 ) The students' memorization improved in finding the meaning. (2) Students' knowledge in indentifying the 
words based on their cluster. (3 ) students' pronunciation improved gardually since they have a lot of parctice.

Finally, song as the media could be used to facilitate teaching learning process, the selection of various song also influence the students' interest in learning. Besides, teaching vocabulary through song improved students' vocabulary, it also imprved students motivation in learning. The students were enthusiastic in following the activity, such as singing, finding the meaning, identifying and memorizying the words. The students responses also supported by the students' score in doing the test. They got good cathegory in test.It meant, the students were motivated to learn vocabulary through song.

\section{REFERENCES}

Ary, D., Jacobs, L. C., Sorensen, C., \& Razavieh, A. (2010). Introduction to Research in Education. Wadsworth: Nelson Education, Ltd.

Best, J. W., \& Kahn, J. V. (2006). Research in Education. Boston: Pearson Education Inc.

Fries, Charles C. 1975. Teaching English as a Foreign Language. An Arbor: The University of Michigan Press.

Griffee, T Dale, 1992,Songs in Action,Phoenix ELT, Herfordshire

Marczyk, G., DeMatteo, D., \& Festinger, D. (2005). Essentials of Research Design and Methodology. New Jersey: John Wiley \& Sons, Inc.

Rai, U. (2010). English Language Communication Skills. Mumbai: Himalaya Publishing house PVT.LTD.

Richards, J. C., \& Farrel, T. S. C. (2005). Proffesional Development for Language Teachers : Strategies for Teacher Learning. New York: Cambridge University Press. 